\title{
Strength Properties of Remoulded Sludge Stabilized with Calcium Carbide Residue
}

\author{
Yuyi Liu ${ }^{1}$,Yunjie $\mathrm{Li}^{3}$ \\ Faculty of Architecture and Civil Engineering, \\ Huaiyin Institute of Technology, \\ Huai'an,China \\ Qi Tang ${ }^{2}$ \\ China Power (Hongze) Thermal Power Co., Ltd., \\ Huai'an, China
}

\author{
Jun $\mathrm{Ye}^{4}$ \\ Jiangsu Huaxin Survey and Design Co., Ltd., \\ Huai'an, China \\ Qin Yang ${ }^{5}$ \\ Faculty of Foreign Language, \\ Huaiyin Institute of Technology, \\ Huai'an,China
}

\begin{abstract}
The sludge is characterized by weak water permeability, low strength and high compressibility. In order to reduce environmental pollution and utilize waste resource, calcium carbide residue(CCR) gained from acetylene plants was used for stabilization of remoulded sludge. Based on unconfined compression test and direct shear test, strength properties of remoulded sludge stabilized with CCR were investigated in this paper. Unconfined compressive strength, cohesion and internal friction angle of remoulded sludge improved significantly after adding CCR, and influenced by blending ratio and curing time. It is interesting that the strength improvement of stabilized sludge is classified into two zones, including active zone and deterioration zone. Based on comprehensive strength, the optimal blending ratio of CCR is advised between $10 \%$ and $15 \%$. Moreover, the main mechanism of CCR to stabilize remoulded sludge are cation exchange and pozzolanic reaction. Because of excellent strength, environmental and cost performance, stabilized remoulded sludge with CCR will be highly concerned in future.
\end{abstract}

Keywords-Remoulded sludge; calcium carbide residue; unconfined compressive strength; cohesion; internal friction angle

\section{INTRODUCTION}

In lakes, rivers and swamps, because of biological action and physical-chemical reactions, a soft silty clay containing a large amount of organic matter and microorganisms is deposited, which always been called as sludge. The porosity ratio of sludge is greater than 1 , and the natural water content is generally much higher than its liquid limit. The sludge is characterized by weak water permeability, low strength and high compressibility. Its bearing capacity is generally less than $50 \mathrm{kPa}$ and not suitable as a foundation soil for construction.

Along with lake dredging, port reconstruction, and river dredging, a large amount of abandoned dredged sludge has been yielded in China. Generally speaking, dredged sludge contains a variety of harmful components and various organic matter. If left untreated, the sludge will cause secondary pollution to local environment.

There are three methods for treatment of dredged sludge: physical, heat and chemical treatment[1]. The chemical

The work was financially supported by the Policy Guidance Program of Jiangsu Provincial (Project code: BY2016061-12) and the Science and Technology Foundation of Construction in Jiangsu Province (Project code: 2017ZD130) treatment method is to add binding materials to sludge. Traditionally, the binders are cement, lime, fly ash and gypsum[2-5].However the common binders are under discussion not only for their negative environmental effects during manufacture but also for their costs. In recent years, scholars have tended to use various types of solid waste as improvers for sludge, such as hydraulic ash[6],iron tailing slag[7],ladle furnace slag[8],steel slag[9] and so on. Of course, there are other kinds of wastes that can be used as curing agents.

Calcium carbide residue (CCR) is a by-product of acetylene production, which contains mainly calcium hydroxide, $\mathrm{Ca}(\mathrm{OH})_{2}$. It was confirmed that $64 \mathrm{~g}$ of calcium carbide $\left(\mathrm{CaC}_{2}\right)$ provided $26 \mathrm{~g}$ of acetylene gas $\left(\mathrm{C}_{2} \mathrm{H}_{2}\right)$ and 74 $\mathrm{g}$ of CCR[10]. According to statistics, the consume of $\mathrm{CaC}_{2}$ in China is 24.47 million tons in 2017,meaning 28.29 million tons of CCR is produced. Theoretically, dried CCR can completely replace lime for foundation treatment. The basic physical, mechanical and microscopic properties of stabilized soil with CCR have been analyzed in past[11-15]. Furthermore its successful application in subgrade engineering, has confirmed its scientific and feasibility in soil stabilizement $[16,17]$.However, until now, utilization of CCR to stabilize sludge has not yet been reported.

The paper aims to stabilize remoulded sludge by making use of CCR from acetylene companies. The unconfined compression strength and shear strength of stabilized expansive soil were studied through a series of experiments. At the same time, the influences of blending ratio and curing time on effectiveness of using CCR to enhance sludge were investigated.

\section{MATERIALS AND METHODS}

\section{A. Materials}

\section{1) Sludge}

Sludge is collected from White Horse Lake in Huai'an, Jiangsu Province, China. The sampling site is shown in Figure 1 and the natural moisture content of sludge is $97.06 \%$. After dried, sludge is crushed into particles with crusher and sieved with sieve size $2 \mathrm{~mm}$. Using laser particle size analyzer, particle size distribution of sludge has been illustrated in Figure 2,and specific surface area has been 
estimated to be $4613 \mathrm{~cm}^{2} / \mathrm{g}$. At the same time, specific gravity, limit moisture content, maximum dry density and optimum moisture content were tested and listed in Table 1 . The soil is classified into $\mathrm{CH}$ clay with high plasticity. The loss on Ignition is as high as 12.52, indicating that organic matter content in sludge is particularly high.

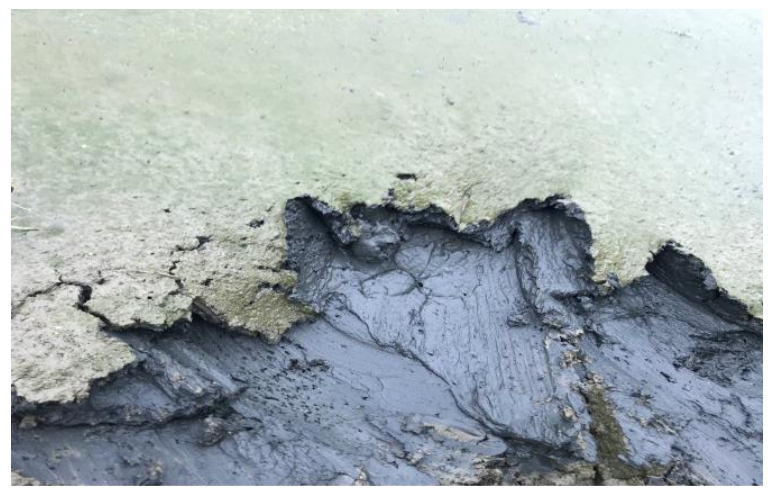

Figure 1. Sludge collected from lake

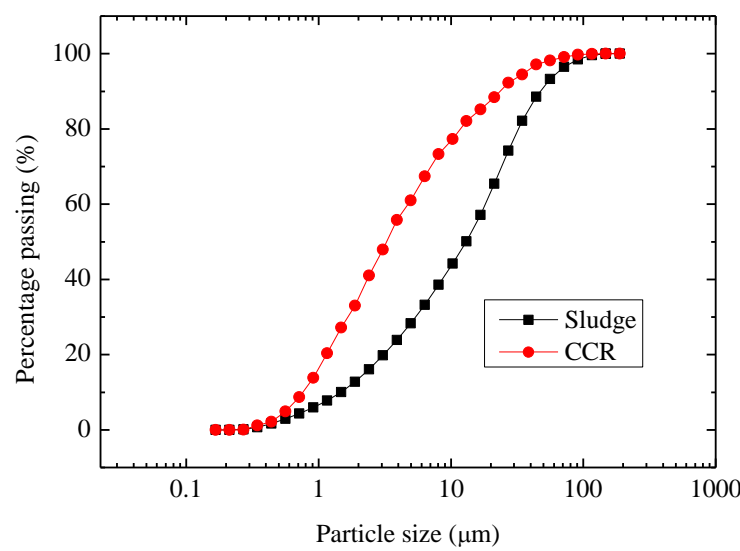

Figure 2. Particle size of sludge and CCR

\section{2) $C C R$}

CCR is gained from waste accumulation pool of acetylene company located in Huai'an, as shown in Figure 3. It has been dried for 24 hours at $105^{\circ} \mathrm{C}$ in oven, then grounded in planetary ball mill. The specific surface area of grounded CCR is $11310 \mathrm{~cm}^{2} / \mathrm{g}$, and particle size is shown in Figure 2 . Its particles are more fine and uniform compared with sludge.

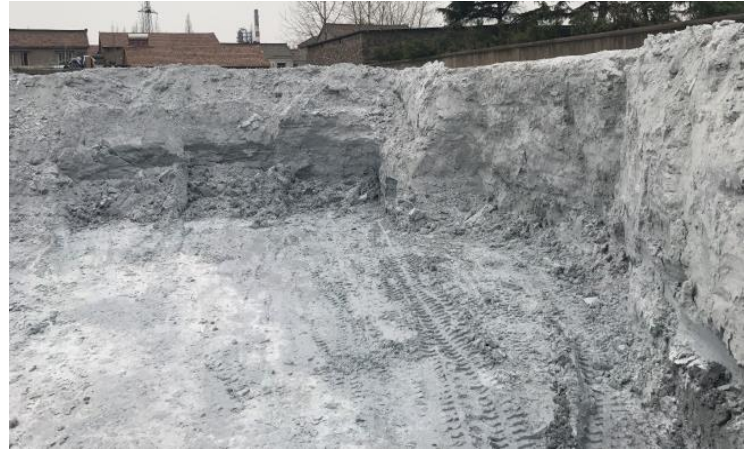

Figure 3. CCR in waste accumulation pool

\section{B. Experiment methods}

\section{1) Samples manufacture}

Frist, experimental materials including sludge and CCR were dried, ground and sieved. Second, dried sludge is blended with CCR. The blending ratio, which is dry mass ratio between CCR and dried sludge in this paper, is designed as $0 \%, 5 \%, 10 \%, 15 \%, 20 \%, 25 \%$. Third, the mixture are stirred with water, then placed in a sealed bag, stewing for 24 hours. Fourth, samples are pressed out by self-made sampler. Fifth, soil samples will been cured at $20^{\circ} \mathrm{C}$ and $90 \%$ humidity until $1,7,28$ days.

\section{2)Testing of samples}

Unconfined compression test and direct shear test are carried out in order to understand effect of CCR on stabilized sludge. All of tests were conducted in the Geotechnical Laboratory, Department of Civil Engineering, Huaiyin Institute of Technology.

\section{RESULTS AND DISCUSSION}

\section{A. Unconfined compression strength}

- The unconfined compressive strength(UCS) versus $\mathrm{CCR}$ content is described in Figure 4 for curing times of 1,7, 28days. Due to addition of CCR, the strength of remoulded sludge is significantly improved. For example, when blending ratio is $10 \%$ and curing only one day, the unconfined compressive strength has been 1.67 times that of untreated sample.

- Curing time has a great influence on unconfined compressive strength of remoulded sludge. For all samples, as curing time increases, unconfined compressive strength increases accordingly. Take blending ratio of $15 \%$ for example, curing after 1,7 and

Table 1 . The physical properties of sludge

\begin{tabular}{cccccccccc}
\hline $\begin{array}{c}\text { Coarse } \\
\text { particle } \\
(\%)\end{array}$ & $\begin{array}{c}\text { Medium } \\
\text { particle } \\
(\%)\end{array}$ & $\begin{array}{c}\text { Fine } \\
\text { particle } \\
(\%)\end{array}$ & $\begin{array}{c}\text { Specific } \\
\text { gravity }\end{array}$ & $\begin{array}{c}\text { Liquid } \\
\text { limit } \\
1 \%\end{array}$ & $\begin{array}{c}\text { Plastic } \\
\text { limit } \\
1 \%\end{array}$ & $\begin{array}{c}\text { Plasticity } \\
\text { index }\end{array}$ & $\begin{array}{c}\text { Maximum } \\
\text { dry density } \\
/ \mathrm{g} \cdot \mathrm{cm}^{-3}\end{array}$ & $\begin{array}{c}\text { Optimum } \\
\text { moisture } \\
\text { content } / \%\end{array}$ & $\begin{array}{c}\text { Loss on } \\
\text { Ignition } \\
1 \%\end{array}$ \\
\hline 3.53 & 56.20 & 30.27 & 2.63 & 52.05 & 29.66 & 22.39 & 1.52 & 24.0 & 12.52 \\
\hline
\end{tabular}


28 days, UCS is $0.98 \mathrm{MPa}, 1.11 \mathrm{MPa}$ and1.24MPa respectively.

- The strength improvement of stabilized sludge is classified into two zones. The first zone, in which strength increases with CCR content, is designated as active zone. In this paper, active zone is blending ratio between $0 \%$ and $10 \%$. The strength decrease appears when blending ratio is higher than $10 \%$. This zone is identified as deterioration zone. It is interesting that for different curing time the optimal blending ratio providing highest strengths is $10 \%$, which is the CCR fixation point. The CCR fixation point indicates the capacity of remoulded sludge to absorb $\mathrm{Ca}^{2+}$ ions and react with $\mathrm{Ca}(\mathrm{OH})_{2}$. Exceeding fixation point, $\mathrm{Ca}(\mathrm{OH})_{2}$ can't completely react with $\mathrm{SiO}_{2}, \mathrm{Al}_{2} \mathrm{O}_{3}$ in the soil.

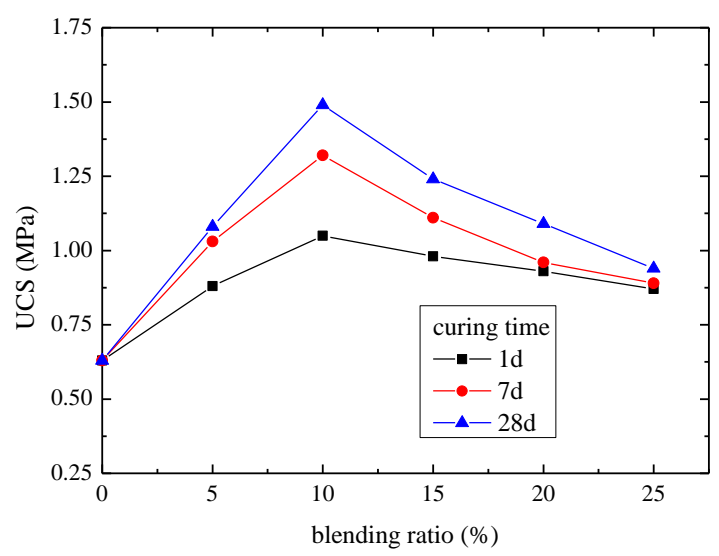

Figure 4. UCS of remoulded sludge stabilized with CCR

\section{B. Shear strength}

The shear strength parameter such as cohesion and internal friction angle was obtained from direct shear test. The roles of curing time for different blending ratio on cohesion development is illustrated in Figure 5.The addition of CCR tends to increase cohesion of remoulded sludge. For example, when blending ratio is $15 \%$ and curing only one day, the cohesion has been 2.80 times that of untreated sample. Same as unconfined compressive strength, cohesion improvement of stabilized sludge is also classified into two zones, including active zone and deterioration zone. But unlike USC, its fixation point is $15 \%$. In addition, the cohesive increases as curing time increases. Take blending ratio of $15 \%$ for example, curing after $1,7,28$ days, cohesive is $127.55 \mathrm{kPa}$, $144.25 \mathrm{kPa}, 162.7 \mathrm{kPa}$ respectively.

- The effect of blending ratio on the internal friction angle is shown in Figure 6. Because of reaction with $\mathrm{CCR}$, internal friction angle of stabilized remoulded sludge has enhanced obviously. For instance, when blending ratio is $10 \%$ and curing 7 days, internal friction angle of remoulded sludge is $29.1^{\circ}$, however the initial internal friction angle is $22.7^{\circ}$. As same as cohesion, internal friction angle is significantly influenced by curing time. The longer the curing time, the larger the internal friction angle. It is very interesting that internal friction angle also reaches the maximum when blending ratio is $15 \%$.
- As a result, the addition of CCR has obviously upgraded shear properties of remoulded sludge, which is beneficial to bearing capacity of foundation soil.

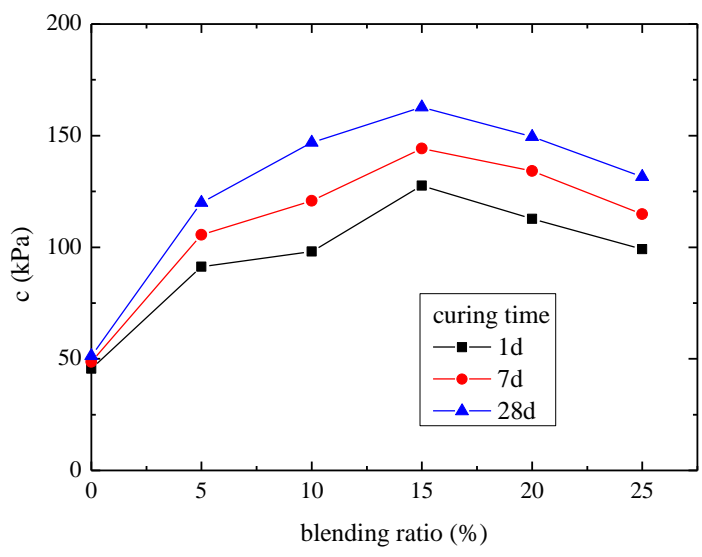

Figure 5. Cohesion of remoulded sludge stabilized with CCR

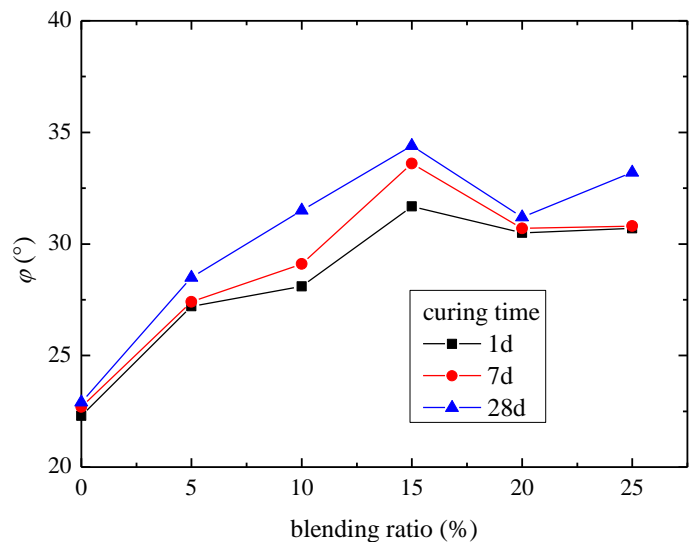

Figure 6. Internal friction angle remoulded sludge stabilized with CCR

\section{Strength developing mechanism}

The above experimental results have demonstrated that remoulded sludge stabilized with CCR has superior mechanical performances than untreated soil. Referring to previous theories about lime-solidified soil[18-20], the excellence in mechanical performance can be interpreted from the physicochemical and microstructural points of view.

- At the early stage of curing, the interaction between CCR and sludge is achieved by cation exchange. The cation exchange between calcium ions from hydration of CCR and the readily exchangeable cations initially adsorbed on the soil particle, results in a reduced thickness of diffusion double layer of clay particles. As a consequence flocculation and agglomeration of soil particles have formatted. In addition, finer particle size and larger specific surface area of CCR particles are preferable for the formation of flocculation and agglomeration.

- The long-term interaction between CCR and remoulded sludge is dominated by pozzolanic reaction. The hydrated materials including $\mathrm{C}-\mathrm{S}-\mathrm{H}, \mathrm{C}-\mathrm{A}-\mathrm{H}$ and $\mathrm{C}-\mathrm{A}-\mathrm{S}-\mathrm{H}$ can be generated due to $\mathrm{Ca}(\mathrm{OH})_{2}$ reacts with reactive $\mathrm{SiO}_{2} / \mathrm{Al}_{2} \mathrm{O}_{3}$ in sludge. These hydrated materials which are ideal 
cementitious and water insoluble, proceeds immediately to coat and bind clay lumps in soil and to block off soil voids. Along with these cementitious materials gradually transforming from gel state to crystalline state, the particle of remoulded sludge are joined together and consolidated.

\section{CONCLUSION}

Some valuable results have been obtained through above experimental, which are summarized as follows.

When the remoulded sludge is stabilized by calcium carbide residue, the mechanical properties of sludge are drastically changed. First, unconfined compressive strength of remoulded sludge raise rapidly when it is blended with CCR. As curing time increases, unconfined compressive strength increases accordingly. Moreover, the strength improvement of stabilized sludge is classified into two zones including active zone and deterioration zone and the optimal blending ratio with highest strength is $10 \%$. Second, the addition of CCR tends to increase cohesion and internal friction angle of remoulded sludge. In addition, the longer the curing time, the larger the cohesion and internal friction angle. But unlike USC, fixation point of shear strength is $15 \%$. The main reasons of stabilization remoulded sludge with CCR are cation exchange and pozzolanic reaction.

Because of excellent strength performance, lowered construction and disposal costs, reduced environmental pollution, stabilized remoulded sludge with CCR will be highly concerned by geotechnical engineers in future. Based on comprehensive consideration of unconfined compressive strength and shear strength, the optimal blending ratio of CCR is advised between $10 \%$ and $15 \%$.

\section{REFERENCES}

[1] Zhu W, Zhang C L, Liu H L,et al.The Status Quo of Dredged Spoils Utilization. Environmental Science and Technology, 2002,25(4),3941,50 .

[2] Brouwers H J H, Augustijn D C M, Krikke B, et al. Use of cement and quicklime to accelerate ripening and immobilize contaminated dredging sludge[J]. Journal of hazardous materials, 2007, 145(1-2),8-16.

[3] Zoubir W, Harichane K, Ghrici M. Effect of lime and natural pozzolana on dredged sludge engineering properties. Electronic Journal of Geotechnical Engineering, 2013, 18(c),589-600.

[4] Wang D, Zentar R, Abriak N E. Durability and Swelling of Solidified/Stabilized Dredged Marine Soils with Class-F Fly Ash,
Cement, and Lime. Journal of Materials in Civil Engineering, 2018 , 30(3),04018013.

[5] Bao J, Wang L, Xiao M. Changes in speciation and leaching behaviors of heavy metals in dredged sediment solidified/stabilized with various materials. Environmental Science and Pollution Research, 2016, 23(9), 8294-8301.

[6] Zhu S J, Qin Y, Hwang J Y. Solidification of dredged sludge by hydraulic ash-slag cementitious materials. Characterization of Minerals, Metals and Materials 2016. Springer, Cham, 2016,255-261.

[7] Chu C, Deng Y, Zhou A, et al. Backfilling performance of mixtures of dredged river sediment and iron tailing slag stabilized by calcium carbide slag in mine goaf. Construction and Building Materials, 2018, $189,849-856$

[8] Pantazopoulou E, Zouboulis A. Chemical toxicity and ecotoxicity evaluation of tannery sludge stabilized with ladle furnace slag. Journal of environmental management, 2018, 216,257-262.

[9] Samara E, Matsi T, Balidakis A. Soil application of sewage sludge stabilized with steelmaking slag and its effect on soil properties and wheat growth. Waste Management, 2017, 68,378-387.

[10] Horpibulsuk S,Kampala A,Phetchuay C,et al.Calcium carbide residue - a cementing agent for sustainable soil stabilization.Geotechnical Engineering Journal of the SEAGS \& AGSSEA, 2015, 46(1),22-27.

[11] Kampala A,Horpibulsuk S,Chinkullijniwat A,et al.Engineering properties of recycled Calcium Carbide Residue stabilized clay as fill and pavement materials. Construction \& Building Materials, 2013, $46,203-210$

[12] Jiang N J,Du Y J,Liu S Y,et al.Multi-scale laboratory tests on the engineering and microstructural properties of soft highway subgrade soil stabilized with calcium carbide residue. Canadian Geotechnical Journal, 2015, 52, 1-11

[13] Jiang N J,Du Y J,Liu S Y,et al. Multi-scale laboratory evaluation of the physical, mechanical and microstructural properties of soft highway subgrade soil stabilized with calcium carbide residue. Canadian Geotechnical Journal, 2016, 53,373-383

[14] Qin X G,Du Y J,Liu S Y. Experimental study on physical and mechanical properties of over-wet clayey soils stabilized by calcium carbide residues. Chinese Journal of Geotechnical Engineering, 2013,35(1),175-180

[15] Du Y J,Liu S Y,Wei M L. Micromechaism of over-wet clayey soils stabilized by calcium carbide residues. Chinese Journal of Rock Mechanics and Engineering, 2014,33(6),1278-1285.

[16] Du Y J,Jiang N J,Liu S Y,et al.Field evaluation of soft highway subgrade soil stabilized with calcium carbide residue. Soils and Foundations, 2016, 56,301-314.

[17] Du Y J,Liu S Y,Qin X G. Field investigations on performance of calcium carbide residues stabilized over-wet clayey soils used as highway subgrade materials. Journal of Southeast University( Natural Science Edition), 2014,44(2),375-380

[18] Ingles O G,Metcalf J B. Soil Stabilization, Principles and Practice, John Wiley \& Son's, Sydney, Australia, 1972,55-98.

[19] Kinuthia J M, Wild S, Jones G I. Effects of monovalent and divalent metal sulphates on consistency and compaction of lime-stabilised kaolinite. Applied Clay Science, 1999,14(1-3),27-45.

[20] Hunter D. Lime-induced heave in sulfate-bearing clay soils. Journal of Geotechnical Engineering, 1988,114(2),150-167. 